\title{
Implementasi Kebijakan Persyaratan Kualitas Air Minum Isi Ulang di Kecamatan Tondano Selatan
}

\author{
Margareth Inof Riisyie Rantung \\ FIS UNIMA \\ Prodi administrasi negara \\ Tondano, Indonesia \\ Margarethrantung@gmail.com
}

Abstrak- Penelitian ini bertujuan untuk menganalisis implementasi kebijakan Persyaratan Kualitas Air Minum Isi Ulang di Kecamatan Tondano Selatan, dengan menggunakan pendekatan kualitatif dan teknik pengumpulan data yaitu: observasi pada pelaku usaha Depot Air Minum Isi Ulang, wawancara semi tersruktur pada pelaku usaha Depot Air Minum Isi Ulang, implementer kebijakan yaitu Dinas Kesehatan Kabupaten Minahasa, Laboran dan dokumen berupa isin usaha, hasil uji kualitas air isi ulang . Hasil penelitian menunjukkan bahwa: a). Kebijakan belum disosialisasikan kepada pelaku usaha Depot Air Minum Isi Ulang dan masyarakat di Kecamatan Tondano Selatan, b) belum terjadi komunikasi yang intensif antara pelaku usaha Depot Air Minum Isi Ulang, implementer kebijakan yaitu Dinas Kesehatan Kabupaten Minahasa, Laboran, c) belum terdapat komitmen yang serius dari implementer kebijakan Persyaratan Kualitas Air Minum Isi Ulang yaitu Dinas Kesehatan Kabupaten Minahasa, d). Kondisi sosial budaya dan ekonomi masyarakat pengguna air minum isi ulang yang belum peduli dengan kualitas air minum yang dikonsumsi. Untuk itu disarankan sebaiknya: a). Kebijakan Persyaratan Kualitas Air Minum Isi Ulang disosialisasikan kepada pelaku usaha Depot Air Minum Isi Ulang dan masyarakat di Kecamatan Tondano Selatan, b) dilakukan komunikasi yang intensif antara pelaku usaha Depot Air Minum Isi Ulang, implementer kebijakan Persyaratan Kualitas Air Minum Isi Ulang yaitu Dinas Kesehatan, Laboran, dan masyarakat pengguna air isi ulang, c) diperlukan komitmen yang serius dari implementer kebijakan dalam memberi isin usaha, melakukan uji laboratorium tentang kualitas air isi ulang, d). Kondisi sosial budaya dan ekonomi masyarakat pengguna air minum isi ulang di berikan pemahaman tentang dampak kesehatan dalam menggunakan air minum isi ulang yang belum memenuhi syarat kualitas air minum isi ulang.

Kata Kunci: Implementasi Kebijakan Persyaratan Kualitas Air Minum Isi Ulang, Kecamatan Tondano Selatan, Minahasa.

\section{INTRODUCTION}

Kebijakan Persyaratan Kualitas Air Minum diatur melalui Peraturan Menteri Kesehatan Republik Indonesia Nomor 492/MENKES/PER/IV/2010 dimana tanggungjawab mengawasi adalah dinas kesehatan Kabupaten khususnya laboratorium Balai Lingkungan Hidup.(1). Data Badan Pengawas Obat dan Makanan menunjukkan bahwa dalam kemasan air isi ulang terdapat bakteri berbahaya yang menimbulkan gangguan kesehatan seperti diare. Hasil penelitian BTKL Regional Sulawesi Utara Gorontalo Maluku Tahun 2014 mengindikasikan bahwa terdapat $40 \%$ Depot Air Minum Isi Ulang di Manado yang tidak memenuhi syarat kesehatan.. World Health Organization (WHO), merilis bahwa $94 \%$ kasus diare diakibatkan oleh bakteri Escherichia Coli (E. Coli), dapat dicegah dengan meningkatkan akses air bersih, sanitasi, perilaku higienis, dan pengolahan air minum skala rumah tangga. Observasi yang dilakukan pada karyawan depotdepot AMIU tidak pernah menggunakan alat pelindung diri seperti masker, handscoen, baju 
khusus, sehingga kemungkinan besar dapat menimbulkan kontaminasi dalam proses pengemasannya dan pemeriksaan karyawan secara berkala jarang dilakukan.(2) Berdasarkan pada beberapa permasalahan tersebut maka dilakukan analisis tentang implementasi kebijakan Persyaratan Kualitas Air Minum pada usaha depot air minum isi ulang di Kecamatan Tondano Selatan.

\section{RESEARCH METHODS}

Penelitian ini menggunakan jenis penelitian kualitatif fenomenologis, dengan tehnik pengumpulan data: observasi pada pelaku usaha Depot Air Minum Isi Ulang di Kecamatan Tondano Selatan, wawancara semi tersruktur pada pelaku usaha Depot Air Minum Isi Ulang, implementer kebijakan Persyaratan Kualitas Air Minum Isi Ulang yaitu Dinas Kesehatan Kabupaten Minahasa, Laboran dan dokumen berupa isin usaha, hasil uji kualitas air isi ulang. Ketiga data tersebut dilakukan trianggulasi. (3).

\section{RESULT AND DISCUSION}

\section{Sosialisasi kebijakan Persyaratan Kualitas Air Minum Isi Ulang, Kecamatan Tondano Selatan}

Edward III (1980: 1) menulis bahwa salah satu isu pokok implementasi kebijakan diantaranya adalah "communication" yang berkenaan dengan bagaimana kebijakan dipahami oleh implementer, sasaran dan masyarakat disekitar kebijakan.(4). Sosialisasi yang dimaksud adalah berkenaan dengan bagaimana kebijakan Persyaratan Kualitas Air Minum Isi Ulang, dipahami dengan benar dan tepat oleh Dinas Kesehatan Kabupaten Minahasa, Laboran sebagai implementer, pelaku usaha Depot Air Minum Isi Ulang, masyarakat pengguna air minum isi ulang di Kecamatan Tondano Selatan. Hasil penelitian yang dilakukan dengan melakukan trianggulasi data observasi, dokumen dan wawancara semi terstruktur kepada pada bagian yang bertanggungjawab atas implementasi kebijakan Persyaratan Kualitas Air Minum Isi Ulang pada Dinas Kesehatan Kabupaten Minahasa, Laboran sebagai implementer,menunjukkan bahwa mereka belum melakukan sosialisasi secara intensif mngenai kebijakan tersebut bahkan mengenai dampak penggunanaan air isi ulang yang belum diuji kualitasnya oleh laboran, bagi kesehatan. Pelaku usaha Depot Air Minum Isi Ulang juga mengakui bahwa mereka belum paham betul tentang persyaratan kesehatan air isi ulang yang mereka jual. Yang pentin bagi mereka adalah bagaimana air minum isi ulang yang dijual laku dibeli oleh masyarakat. Belum ada pilihan bagi mereka untuk melakukan usaha lain selain membuka depot air minum isis ulang, sebagai upaya memenuhi kebutuhan hidup sehari-hari. Masyarakat pengguna juga belum paham dengan benar tentang kualitas air isi ulang yang mereka minum bahkan belum paham tentang dampak buruk bagi mereka jika menggunakan air minum isi ulang. Berdasarkan hasil analisis tersebut maka dapat dikatakan bahwa sosialisasi harus dilakukan dengan benar dan tepat agar semua pihak yang telibat dalam implementasi, masyarakat pengguna an pelaku usaha dapat memahami dengan benar dan tepat mengenai persyaratan kualitas kesehatan air minum isi ulang di kecamatan Tondano Selatan. Selain sosialsasi kebijakan maka masyarakat juga harus memahami tentang hasil uji Badan Pengawas Obat dan Makanan yang menunjukkan bahwa dalam kemasan air isi ulang terdapat bakteri berbahaya yang menimbulkan. Begitu juga dengan hasil penelitian BTKL Regional Sulawesi Utara Gorontalo Maluku yang menemukan $40 \%$ Depot Air Minum Isi Ulang di Manado belum memenuhi syarat kesehatan, World Health 
Organization (WHO) yang merilis bahwa kasus diare diakibatkan oleh $94 \%$ bakteri Escherichia Coli (E. Coli) dan upaya pencegahannya dengan menggunakan air bersih, sanitasi, perilaku higienis, dan pengolahan air minum rumah tangga. Bahkan perlu juga mensosialisakan mengenai hasil observasi pada karyawan depot-depot AMIU yang belum menggunakan alat pelindung diri yang dapat menimbulkan kontaminasi dalam proses pengemasannya.

\section{Komunikasi antara implementer kebijakan} Persyaratan Kualitas Air Minum Isi Ulang yaitu Dinas Kesehatan Kabupaten Minahasa, Laboran dan pelaku usaha Depot Air Minum Isi Ulang

Mazmanian dan Sabatier (1986: 4) menulis bahwa dalam memahami implementasi kebijakan berarti berusaha memahami apa yang terjadi sesudah sesuatu program dilaksanakan atau dirumuskan, dalam arti setiap pihk yang terlibat dalam implementasi kebijakan sebaiknya melakukan komunikasi secara intensif agar tejadi koordinasi yang baik antara implementer teknis, lapangan dan masyarakat pengguna air isi ulang serta pelaku usaha air minum isi ulang (5). Ketika kebijakan diimplementasikan maka harus dilakukan evaluasi kebijakan mengenai keadaan yang terjadi sesudah ketika kebijakan diimplementasikan. Mengacu pada pandangan Edwards III merumuskan empat aspek diantaranya aspek komunikasi. (6).

Hasil penelitian menunjukkan bahwa ketika pelaku usha depot air minum isi ulang di Kecamatan Tondano Selatan menjual air minum isis ulang, mereka mengakui bahwa aa diantara mereka yang belum memiliki isisn usaha, bahkan kualitas air minum isi ulang yang mereka jual belum diuji oleh laboran. Disisi lain mereka juga belum memehami persyaratan bagi pekerja yang melakukan isi ulang. Kebijakan ini sudah lama diimplementasikan, tetapi dalam kenyataannya mereka belum pernah didatangi oleh laboran dan dinas Kesehatan Kabupaten Minahasa untuk memeriksa ijin usaha, kualitas air minum isi ulang yang mereka jual. Keadaan ini menunjukkan bahwa belum terjadi komunikasi yang intensif antara imlementer teknis, implementer lapangan denga pelaku usaha depot air minum isi ulang. Padahal secara teoritik para ahli menganjurkan bahwa keberhasilan implementasi kebijakan ditentukan oleh faktor komunikasi.

\section{Komitmen yang serius dari implementer} kebijakan Persyaratan Kualitas Air Minum Isi Ulang yaitu Dinas Kesehatan Kabupaten Minahasa dan laboran.

Disposisi atau komitmen pemerintah Kabupaten Minahasa khususnya Dinas Kesehatan dan Laboratorium sebagai pihak yang mengimplementasikan kebijakan Persyaratan Kualitas Air Minum Isi Ulang bagi pelaku usaha depot air minum isi ulang sangat diperlukan. Karena kebijakan yang dirumskan dengan baik, tidak akan membawa dampak postif jika belum terdapat komitmen yang serius dari implementer teknis dan lapangan. Disposisi merupakan faktor determinan dalam keberhasilan implementasi kebijakan. Van Meter dan Van Horn mengkalasifikasikan aspek disposisi sebagai karakteristik penentu keberhasilan kebijakan. (7). Mazmanian dan Sabatier mengkalasifikasikan disposisi pada faktor independen sebagai salah satu bentuk dukungan dan komitmen pejabat pelaksana. (8). Hogword dan Gunn mengkalasifikasikan disposisi sebagai kualitas dan komitmnen para pihak, (9). Elmore mengkalasifikasikan disposisi sebagai tanggngjawab pemerintah terhadap implementasi kebijakan, (10). Edward mengkalasifikasikan disposisi sikap prilaku implementer. Dukungan implementer dapat dinilai dari terlihat pada keseriusan 
mereka menempatkan implementasi kebijakan Persyaratan Kualitas Air Minum Isi Ulang bagi pelaku usaha depot air minum isi ulang sebagai prioritas karena air minum merupakan kebutuhan pokok manusia dalam kehidupan sehari-hari. Disposisi pemerintah Kabupaten Minahasa khususnya Dinas Kesehatan dan Laboran sangat diperlukan karena data Badan Pengawas Obat dan Makanan mengemukakan bahwa kemasan air isi ulang ternyata terdapat bakteri berbahaya begitu juga dengan BTKL Regional Sulawesi Utara Gorontalo Maluku yang mengumumkan bahwa $40 \%$ Depot Air Minum Isi Ulang di Manado belum memenuhi syarat kesehatan, dan kondisi tersebut diperkuat lagi dengan pengumuman WHO dimana $94 \%$ kasus diare yang diakibatkan bakteri Escherichia Coli dapat teratasi jika akses air bersih, sanitasi, perilaku higienis, dan pengolahan air minum skala rumah tangga dikelola sesuai persyaratan. Kondisi ini jka dibiarkan akan berdampak bagi kesehatan masyarakat pengguna air minum isi ulang di kecamatan Tondano. Untuk itu sebagai pemerintah dn penanggungjawab kebijakan maka sangat diperlukan disposi dalam ati komitmen yang sangat sungguh-sungguh agar pelaku usaha depot air minum isi ulang di Kecamatan Tondano Selatan memperhatikan persyaratan kualitas air minum yang dijual. Pemerintah perlu melakukan pembinanaan an pengawasan kepada pelaku usaha dan karyawan depot air minum isi ulang sebagai bentuk komitmen menjaga kesehatan masyarakat kecamatan Tondano Selatan.

\section{Kondisi sosial budaya dan ekonomi} masyarakat pengguna air minum isi ulang. Kondisi so sosial budaya dan ekonomi masyarakat pengguna air minum isi ulang meupakan aspek determinan implementasi kebijakan.

Masyarakat pengguna air minm isi ulang diposisikan sebagai penentu imlementasi kebijakn karena pada dasarnya kebijakan persyaratan kualitas air minum isi ulang di rumuskan dalam rangka melindungi masyarakat dari bahaya gangguan kesehatan. Namun bagaimana masyarakat memahami persyaratan kualitas air minum dan dampak dari menggunakan air minum yang belum memenuhi persyaratan kebijakan jika masyarakat sendiri belum memahami kebijakan tersebut. Sepanjang masyarakat belum memahami kebijakan maka masyarakat akan menunjukkan prilaku tidk mendukung implementasi. Jadi tumbuh suburnya depot air minum isi ulang yang belum memenuhi standar kebijakan, akan terpelihara dengan sendirinya. Untuk itu upaya mendukung implementasi kebijakan dari mempersiapkan kondisi sosial budaya masyarakat sangat penting dilakukan. Hal ini dilakukan agar terjadi sinergi antara implementer, pelaku usaha dan masyarakat pengguna air minum isi ulang. Hal ini sejalan dengan logika top-down dan bottom- up dimana Agustino (2006:155) menjelaskan pendekatan implementasi kebijakan dengan pendekatan top down yang serupa dengan pendekatan command and control (Lester Stewart, 2000:108) dan pendekatan bottom up yang serupa dengan pendekatan the market approach (Lester Stewart, 2000:108). Pendekatan top down atau command and control dilakukan secara tersentralisasi sedngkan pendekatan bottom up lebih menyoroti implementasi kebijakan yang terformulasi dari inisiatif masyarakat,(11). Kondisi sosial masyarakat tekadang belum siap menunjang implementasi kebijakan untuk itu pemerintah Kabpaten Minahasa sebaiknya berupaya menciptakan suatu kondisi yang menunjang implementasi kebijakan.

\section{ACKNOWLEDGMENT}

Kepada dosen Program Studi Administrasi Negara yang telah membantu peneliti dalam penyelesaian penelitian dan pembuatan artikel. 


\section{REFERENSI}

[1] Peraturan Mentri Kesehatan No. 9 tahun 492/MENKES/PER/IV/2010 Persyaratan Kualitas Air Minum

[2] Rantung, Margareth, Tanggungjawab Hukum Pemerintah Kabupaten Minahasa Terhadappengawasan Kualitas Air Minum Usaha Depot Air Minum Isi Ulang, Thesis, 2017

[3] Miles Matthew B A. Michael Huberman, Analisis Data Kualitatif , Terjemahan Tjetjep Rohendi Rohidi. Jakarta: UI-Press, 2007

[4] Edward III, George C, Implementing Public Policy. Washington DC: Congressional Quarterly Press, 1980

[5] Mazmanian Daniel and Paul A. Sabatier (eds), Effective Policy Implementation. Lexington Mass DX: Health, 1981

[6] Edward III, George C, Implementing Public Policy. Washington DC: Congressional Quarterly Press, 1980

[7] Van Meter dan Van Horn Edwards III. George C, Implementing Public Policy. Congressional Quarterly Press. Washington D.C,1980

[8] Mazmanian Daniel and Paul A. Sabatier (eds), Effective Policy Implementation. Lexington Mass DX: Health, 1981

[9] Goggin, Malcolm L et al, 1990, Implementation, Theory and Practice, Scott, Foresmann and Company, USA., Robert A et al. 1997

[10] Elmore, R.F, Forward and Backward Mapping. In K. Hanf and T.A.J. Toonen (eds), Policy Implementation in Federal and Unitary Systems, pp. 33-70. Dordrecht: Martinus Nijhoff, 1985

[11] Agustino, Leo, Dasar-Dasar Kebijakan Publik. Bandung: Alfabeta, 2012 
Jurnal Kajian Kebijakan dan Ilmu Adminstrasi Negara (Jurnal ADMINISTRO)

http://ejournal.unima.ac.id/index.php/administro 